\title{
PROFESSORS OF PRACTICE: REINVENTING THE PROFESSORIAL ROLE
}

\author{
James Dzisah ${ }^{1}$ \\ Henry Etzkowitz ${ }^{2}$
}

\begin{abstract}
There is an ongoing transformation of the university to add value and strengthen teaching, research and technology transfer capabilities. However, one means of enhancing the university's new social and economic development mission is by reinventing the professorial role through the concept of 'Professors of Practice'. Initially used to bring distinguished practitioners into the university as teachers, the concept is now being applied to research and entrepreneurship. 'Professors of Practice' may link business and science departments and provide entrepreneurial role models for faculty and students.
\end{abstract}

Keywords: Professors of Practice; Entrepreneurial University; Triple Helix; Polyvalent Knowledge

\footnotetext{
${ }^{1}$ Newcastle University Business School, United Kingdom. .e-mail: j.s.dzisah@ncl.ac.uk.

${ }^{2}$ Newcastle University. e-mail: henry.etzkowitz@ncl.ac.uk.
} 


\section{INTRODUCTION}

In a science-based global economy, a flow of commercializable knowledge is the ultimate condition for long-term success. The emergence of polyvalent research fields with simultaneous theoretical, technological and commercial potential provides a substrate for a new kind of innovations. Univalent knowledge follows a sequence from basic to applied research typically carried out in different time periods, at different sites, and by different people. In a polyvalent knowledge environment, the concept of translational research-a less defined notion than applied researchand an activity that is closely associated with fundamental investigation and likely to be conducted in tandem becomes paramount and leads the way in transforming and reinventing the professorial role (Viale and Etzkowitz, 2005).

In fact, universities have multiple missions. The teaching university is based on education and dedication to human capital development. The research university combines production of knowledge with teaching in a creative tension that has proven more productive than the separation of these activities. The entrepreneurial university takes these two functions further by adding the pursuit of economic outcomes of research or service for society as an extension of the social and economic development mission of universities. In the course of the 'second academic revolution', following the academic revolution that integrated research with teaching, the university is raising its new mission of economic and social development to the same level as its previous missions.

Entrepreneurial universities emerged from strikingly different academic foundations, with the first revolution, research at times occurring simultaneously with the second revolution of economic and social development. Typically, an entrepreneurial mode marks a step change for a research university. However, this can also be a strategy for ENGEVISTA, v. 9, n. 2, p. 166-173, dezembro 2007 growth from a teaching university, with the phases accomplished in tandem or even in reverse order to the usual progression. In fact, the argument is that the typical ivory tower model offers a less effective way of taking full advantage of the immense collaborative potential that university-industry interactions can generate. As such, the expectation is that the presence of an entrepreneurial university, which generates new fields of research with theoretical and commercial potential, would make a significant difference to economic organization (Viale and Etzkowitz, 2005). That is why the State University of Rio de Janeiro, Friburgo campus began with a $\mathrm{PhD}$ program in information technology, accompanied by an incubator, in an innovative academic and regional development strategy.

Consequently, some faculty members are viewing their research and teaching in a new light, looking to contribute to technology transfer and firm-formation as well as to education of students and the advancement of knowledge (Etzkowitz and Dzisah, 2007). This transformation is aided by the emergence of such fields as nanotechnology, genomics and materials science which require the intellectual and organization skills, as well as, resources of academic and non-academic players. This new institutional transformation has necessitated interdisciplinarity, and crossinstitutional linkages among diverse network of actors (Gibbons et al., 1994). In the process, the boundary between 'curiosity driven' and 'applied research' is no longer distinct (Viale and Etzkowitz, 2005). It is, indeed difficult, for one to imagine a faculty member in the department of environmental engineering, nanotechnology or medicine, pursuing the so-called "curiosity driven" research by itself (Baber, 2006).

This institutional transformation is reflected in the development of new legal frameworks that provide a basis for resolving conflicts arising from the emergence of new modes of production (Gibbons et al. 1994). Through the 
creation of organizational mechanisms to enhance interactions across the Triple Helix of university-industry-government interface, what is peripheral and what is central to innovation has been transformed making innovation, a concept that was largely limited to product development in the firm, taking on a broader meaning of "innovation in innovation,” (Etzkowitz, 2008). As a result, institutions taking non-traditional roles, such as, universities have become the potential sources of innovation by utilising both formal and informal organizational capabilities to transfer technologies.

While the creation of an interface mechanism is one way of bridging the discovery and application gap, a new format for Triple Helix interaction is tailored around the reinventing of the professorial role through the utilization of the concept of 'Professors of Practice'. At the Massachusetts Institute of Technology (MIT) and Stanford, the two most successful entrepreneurial universities, the tasks of the 'second academic revolution' are peripheral to the faculty role with the notable exception of a relatively few 'serial entrepreneurs.' In a previous era, before the rise of Boston Route 128 and Silicon Valley as the world's pre-eminent high-tech clusters, these universities took a more active entrepreneurial role. MIT incubated firms in its laboratories during the early post war era in collaboration with American Research and Development (ARD), the first venture capital firm, that it helped found. During the depression, Frederick Terman, who has been called 'the father of Silicon Valley' ran a patenting and licensing operation from his faculty office in Stanford's Engineering School, trading intellectual property for fellowship funds for his graduate students. In the late $19^{\text {th }}$ century, when MIT was an engineering teaching college, independent consulting engineers were invited into the university as professors in order to jump-start research (Etzkowitz, 2002).
A similar phenomenon may be currently identified in connection with the expansion of the university's economic and social development mission through the reinventing of the professorial role. This paper focuses on the utilization of 'Professors of Practice' (PoP) as a strategy to enhance academic entrepreneurship and innovation-based regional development.

\section{TRIPLE HELIX LINKAGES}

The Triple Helix thesis is derived from the changing role of government in different societies in relation to academia and industry. It comprises three basic elements: a more prominent role for the university in innovation, on a par with industry and government in a knowledge-based society; the movement toward collaborative relationships among the three major institutional spheres in which innovation policy is increasingly an outcome of interaction rather than a prescription from government; and in addition to fulfilling their traditional functions, each institutional sphere also 'takes the role of the other' in a creative tension. Accordingly, universities, which before now were primarily seen as sources of human resources and knowledge, are now looked to for science and technology innovations as well. In addition, they are extending their teaching capabilities from educating individuals to shaping organizations in entrepreneurial education and incubation programmes.

The Triple Helix model places a greater emphasis on interaction, external linkages and collaboration. It represents a radical departure from attempts to separate the three institutional spheres from active engagement in social and economic development. The new focus in bringing these three complementary but distinct spheres to work closely reflects the polyvalent nature of knowledge and characterized the inter-dependence among relatively autonomous institutional spheres. It takes place from divergent starting points of 'statist' and 
'laissez-faire' regimes. In some countries, there is a movement away from an assumption that has single starting point of research and an end point of the economy: an autonomous linear model based on laissez-faire assumptions in which innovation takes its own course. In other countries in transition from a central planning to a market economy, a role for government was temporarily lost. But, it is increasingly being recognized that government plays an important, if sometimes hidden, role in innovation in market economies. Government programs have an important role to play, not only from the national level-top-down, but also from the local level-bottom-up. This represents a movement from a 'hands off' linear to an 'assisted linear' model of innovation (Etzkowitz, 2006).

However, in regions where the possibility of partnership between firms, government research labs and university centres are strong and encouraged, the triple helix collaborative linkages may be quickly embedded within the professorial role. In regions where these structures are weak, there is the need to provide sufficient incentives for collaborative linkages. A novel attractor being used to incentivize academic entrepreneurship in different support regimes is the concept of 'Professors of Practice'. In fact, the concept was initially tied to teaching but has since been remolded to include academic entrepreneurship marking, a transition from a teaching or research university to that of an entrepreneurial university.

\section{ANTECEDENTS PRACTICAL EXPERIENCES}

AND

In most universities in the United States, the concept of the 'Professors of Practice' are similarly titled "professors of the practice, practice professors, and professors of professional practice" and in all its varied forms, they are exclusively used to refer to non-tenure faculty whose primary duty is to teach. This process is similar to the 'adjunct professorship' and the 'research professor' who have limited and specific duties. At the MIT, the concept was reserved for distinguished practitioners who have had a world class impact on fields important to its academic programs, and to those committed to enhancing those programs. MIT's first 'professor of practice' was jointly appointed in Management and Engineering in 1998. He was Maurice Holmes, a long-time Xerox Corporation engineer and manager. This was followed by the appointment of Gerhard Schulmeyer, the former head of the Siemens Corporation as a 'Professor of Practice' by the MIT Sloan School in 2000 (MIT Alumni Association, 2001).

There are similar instances of the use of the 'Professors of Practice' (PoP) concept for teaching purposes in other US universities. According to the Association of American University Professors (AAUP), 'professors of professional practice' have commonly been reserved for practitioners who are appointed because of skills and expertise acquired in non-academic careers. Though such appointments are also being offered to individuals with academic backgrounds, these 'PoPs' are principally engaged in teaching and are not expected to be significantly involved in research activities (AAUP, 2006).

However, our examination of the recruitment activities of a sub-set of hightech entrepreneurs with strong academic credentials and research interests as 'PoPs' suggest a move towards the reformulation of the professorial role. The move towards the hybridization of the 'Professors of Practice' concept in our view is the realisation that the traditional model of university-industry relations, a lump sum payment in exchange for first review of intellectual property rights (e.g. Novartis/Scripps) is becoming unproductive. This stems from the tendency for company priorities to shift, and also, the fact that the early stage nature of academic findings with commercial potential in most instances requires a translational research process. Indeed, packaging the innovation in a 
start-up that can be acquired is often the requisite for large firms.

These high-tech entrepreneurs have developed lines of innovative research within their firms but these findings require further work that is more appropriate to an academic than a firm setting. The prospect of a professorship, allowing them to build an academic research group and obtain grant funding, has the potential to be a 'pull force' for these scientific entrepreneurs to relocate. These new hybrid professors add value and strengthen the teaching, research and the technology transfer capabilities of the university (Etzkowitz and Dzisah, 2007).

\section{PROFESSORS OF PRACTICE (POP)}

A 'Professor of Practice' integrates business and academic roles and collapses the university-industry divide, turning a conflict of interest into a confluence of interest. The 'PoP' concept, with a half-time role in the university and a half-time commitment to an enterprise, was extrapolated from a particular instance in the Haas Business School, University of California, Berkeley, where a so-called 'PoP', together with a junior associate, heads an Entrepreneurship Centre and manages a "stable of adjuncts," full time business people who teach individual specialized courses in the Haas entrepreneurship specialty within the MBA programme. The 'PoP' is also utilized at the Kennedy School of Government, Harvard University, for full-time faculty members, who hold the $\mathrm{PhD}$ and are internationally recognized public intellectuals in their field.

To date, the most far reaching version has been put into action by Newcastle University. The northeast United Kingdom, a source of the original industrial revolution, is determined to reverse its fate as a declining industrial region. Facing a situation similar to MIT and New England in the early $20^{\text {th }}$ century, Newcastle University initiated a 'Science City' project to regenerate the ENGEVISTA, v. 9, n. 2, p. 166-173, dezembro 2007 region through knowledge-based economic development, focusing on four themes: vitality and health, energy and environment, molecular engineering, stem cell and regenerative medicine. The implementation plan seeks to redevelop a former industrial site with laboratories for firms and university research groups.

The initial concept was to encourage academic and firm scientists to "rub shoulders' through informal interaction in contiguous labs in the expectation that joint projects would be generated. However, a smaller scale 'Centre for Life (CEL)' project, based on a similar principle has been unable to attract a significant number of high-tech enterprises to the region and has devolved into a location for university research groups and a small number of academic spin-offs.

However, to jump-start the attraction of high-tech firms to the region, Newcastle University has turned the 'PoP' concept on its head, from a teaching to a research model. An initial set of four chairs, half supported by the university and half by One Northeast, the regional development agency, has been created. The 'Professors of Practice' who are PhDs and high-tech firm founders in the broad areas of vitality and health, energy and environment, molecular engineering, stem cell and regenerative medicine hold appointments in the Business School. They are encouraged to develop projects linking science and business in collaboration with Science City theme leaders and the Business School. The 'PoPs' are expected to make a significant contribution in developing translational activities and associated education programmes. In addition to bridging links to the external community, they are to enhance the relationships between the academic scientists and the Business School.

Since the PoPs are deemed to have developed ideas for research that are too advanced to be carried out in their firms but could be the basis for a university research group that would attract external funds, they are expected to come together 
in various forums to develop strategies and deliver Science City activities. They are to work in a designated research and teaching domain, working closely with academic staff and their teams to help shape the relationship between the university, users, partners, public sector organisations and business. So far, the four highly successful scientific entrepreneurs appointed as 'Professors of Practice' includes a firm founder whose firm was floated on the London Stock Exchange, and another firm founder who raised about $£ 30$ million in equity financing within two years. The optimum expectation is that all or part of a professor of practice's firm might follow them to Newcastle.

Within the university, the 'PoP' is expected to serve as a role model for faculty members contemplating initiating a start-up and, also, as a link between the university's Business School and Science and Engineering Departments.

The 'PoP' is an instantiation of the Triple Helix innovation in which the university on par with industry and government has become a key innovation actor. In this Triple Helix innovation, the formation of science-based firms from the research of higher educational institutions has taken centre stage. The triple helix provides a flexible framework to guide efforts, from different starting points, to achieve the common goal of knowledge-based economic and social development. As such, in principle, the 'PoP' model can be used to combine internal and external roles in any of the three main missions of the university: teaching, research and regional development.

In addition, the concept may be extended to other areas of the university and from senior to junior positions. For example, the English Department could draw in a $\mathrm{PhD}$ from the publishing industry to help start a university press. The concept can also be reversed by making it applicable to faculty members engaging in start-up activity in a serious but not full-time capacity, obviating the need to make a choice to leave the university completely. As some faculty members move from a ENGEVISTA, v. 9, n. 2, p. 166-173, dezembro 2007 regular full time professorship to a halftime 'Professor of Practice', they will complement those coming into the university, creating a two way flow between university and industry and thus uniting the forward linear and the reverse linear flows. The forward linear denotes the possibility of professors doing startups moving from a regular full time professorship to a half-time 'PoP' to complement those 'PoPs' coming in from outside the academia as a way of raising additional resources to expand the number of those coming in from the worlds of business or public service. This provides a pathway to reinvent the professorial role.

\section{INTELLECTUAL PROPERTY AND CONFLICTS OF INTEREST}

The 'Professors of Practice' concept is meant to encourage innovation and, as such, there is the need for an enhanced Technology Transfer Office (TTO) that will be decentralized into schools and research units. One model is the Columbia University Medical School, where a researcher was given a half-time appointment in the university's TTO, making her the liaison between the office and her department. This half-time position has since grown into a sub-unit of the university TTO. We envision a similar but much broader decentralization of TTO activities into all schools within the university. This will entail a significant increase in staffing of the central Business Development Office and the development of an incubator programme that is also decentralized throughout the university, following the University of Rio, Grande Del Sul model, where incubators are located in the biological science departments alongside laboratories.

Since technology transfer and incubation are central to the 'PoP' concept, there is the need to strategically deal with issues of conflicts of interest. The ethical requirement is not to prohibit conflicts of interest but to regulate and adjudicate conflicting legitimate interests. The 
development of a controversy is often the prelude to negotiating a compromise, with each side having its essential interests taken into account. A controversy is an indicator that significant positive social change may be underway. It is also a sign that an old order is changing, yielding place to new (Etzkowitz, 2002).

In an emerging entrepreneurial university environment, we must break the rules of separation designed to reduce conflicts of interest by turning them into confluences of interest. This requires that we negotiate flexible terms for intellectual property management and ownership recognizing the legitimate and conjoint interest of the university, the faculty member and the firm. Just as academic patenting underwent a transformation as professionalisation of technology transfer creates an organizational search, marketing and business development capabilities, so may the 'Professors of Practice'.

\section{CONCLUSION: BREAKING BOUNDARIES/BUILDING BRIDGES}

The 'Professors of Practice' have the capacity to complete a virtuous circulation of academic development and social engagement, and may form the basis of enhancing diversity within the academia. We have, in recent times, observed among some universities, a behavioural and attitudinal change beyond the extension of teaching capabilities from educating individuals to shaping organizations in entrepreneurial education and incubation programs. This new normative change involves the use of personnel with experiences derived from external settings as well as the reformulation of traditional professorial formats. In this context, the introduction of 'PoP' in teaching, research and entrepreneurial variants has become one mechanism for speeding the transition of academic missions.

While there is no single organizational model to follow, different approaches to entrepreneurship may be identified, depending upon local academic traditions, the previous relationship between the university, industry and government, and current regional development strategies. Thus, a university in a region without significant innovation resources must play a proactive role in order to achieve knowledge-based economic growth. Conversely, a university in a region with a highly developed innovation ecosystem can maintain strong boundaries and still contribute to knowledge-based innovation.

In a highly developed entrepreneurial university, separation can be reintroduced because the external environment around the university is so strong (O'Shea, and, Allen, 2005). However, in aspiring and emerging regions, drawing together resources of triple helix actors in integrated framework is often necessary to jump start the process of knowledgebased economic growth. The creation of successful clusters is based on a creative utilisation of entrepreneurial and research talents from academic, industrial and government sources in creative combination, individually and collectively. The 'Professors of Practice' is one model for integrating entrepreneurial and academic roles, drawing in research talent from outside the university and providing a pathway for academic entrepreneurs to establish new ventures without having to break their ties to the university.

\section{REFERENCES:}

1. AAUP.2006. Professors of Practice 2004. Last visited July 24, 2007. http://www.aaup.org/AAUP/About/com mittees/committee+repts/CommA/Practic e.htm?wbc_purpose=Basic\&WBCMODE =PresentationUnpublished?PF=1

2. Baber, Z. 2006. "Globalization, Nostalgia and the University" " Society 43 (4):44-45.

3. Etzkowitz, H. 2008. The Triple Helix: University-Industry-Government 
Innovation in Action. New York \& London: Routledge.

4. 2006. "The new visible hand: an assisted linear model of science and innovation policy" Science and Public Policy 33 (5): 310-320.

5. 2002. MIT and the Rise of Entrepreneurial Science. London and New York: Routledge.

6. and J. Dzisah. 2007. "Professors of Practice and the Entrepreneurial University” International Higher Education 49:10-11.

7. Gibbons, M., C. Limoges, H. Nowotny, S. Schwartzman, P. Scott and M. Trow (1994) The New Production of Knowledge. London: Sage Publications.

8. MIT Alumni Association. 2001. "Professors of Practice", Last visited July 24, 2007. http://alumweb.mit.edu/opendoor/200104 /practice.shtml

9. O'Shea, R. P. and, T. J. Allen. 2005. "Creating the Entrepreneurial University: The Case of MIT" (June 16, 2005). Available at SSRN: http://ssrn.com/abstract=783866

10. Viale, R., and H. Etzkowitz. 2005. "Third Academic Revolution: Polyvalent Knowledge; The "DNA" of the Triple Helix." in Triple Helix 5. Turin, Italy. www.triplehelix5.com Last visited July 25, 2007. 